\title{
Evaluation of European Railway Companies Efficiency: Application of a Two- Stage Analysis
}

MARKO V. KAPETANOVIĆ, University of Belgrade,

Faculty of Transport and Traffic Engineering, Belgrade MILOŠ S. MILENKOVIĆ, University of Belgrade,

Faculty of Transport and Traffic Engineering, Belgrade NEBOJŠA J. BOJOVIĆ, University of Belgrade,

Faculty of Transport and Traffic Engineering, Belgrade ZORAN Ž. AVRAMOVIĆ, University of Belgrade,

Faculty of Transport and Traffic Engineering, Belgrade
Orginal scientific paper

UDC: $656.2(4)$

DOI: 10.5937/tehnika1703403K

The aim of this paper is efficiency assessment of railway companies from larger Europe during the most recent time period, taking into account different input-output configurations. For this aim, two-stage analysis is employed, where efficiency scores are obtained by DEA in the first stage, while in the second stage different statistical tests are conducted and Tobit analysis is used in order to evaluate influence of different environmental factors. It has been found that railways were oriented either on passenger or freight transportation, with only few companies demonstrating high performance in both modes. While companies from Western Europe showed higher performance than companies from Central and Eastern Europe regarding passenger and overall transportation, this is not the case concerning freight transportation. Except for few companies, there are no clear trends in performance during the period observed, in terms of constant efficiency level increase or decrease. Great impact of factors selection on results has been identified.

Key words: railways, efficiency, data envelopment analysis, Tobit analysis

\section{INTRODUCTION}

Efficiency represents one of the most important performance indicators in railway sector. Since the railway transport plays an important role in economic development of a country [21], evaluation, monitoring and improving efficiency level is the main goal for each railway company.

Different parametric and non-parametric approaches have been used in order to measure and compare performance of railway companies. Two most commonly used methods in efficiency evaluation of railway companies in the recent years are Data Envelopment Analysis (DEA) and Stochastic Frontier Analysis (SFA). DEA is a non-parametric linear programming technique which has successfully been used in

Author's addres: Marko Kapetanović, University of Belgrade, Faculty of Transport and Traffic Engineering, Belgrade, Vojvode Stepe 305

e-mail: m.kapetanović@sf.bg.ac.sr

Paper received: 05.05.2017.

Paper accepted: 25.05.2017. evaluation and comparison of companies' efficiency in the service sector. While some papers employ only one of them, there are papers which use both approaches in order to compare performance of the railways [6]. There can be found many modifications of DEA approach in the literature, e.g. $[8 ; 9 ; 20 ; 21]$. In addition to the efficiency level evaluation, some papers measure the productivity and efficiency change of railways [12, 15]. Malmquist index can be used to detect the sources of changes in the frontier, i.e. technological change as a factor of the rise in outputs.

In addition to these approaches, second-stage analysis is often used in order to evaluate the influence of environmental and exogenous factors on efficiency, by using different techniques $[1 ; 13]$. Tobit method combined with DEA is the most commonly used technique in the two-stage analysis $[4,15,17,18,19]$.

It has been identified that railway companies from Western Europe (WE) and Central and Eastern Europe (CEE) show different level of efficiency, as well as that there are large differences between passenger and freight transportation performances of railways [13; 
21]. Despite this fact, there is a small number of papers that concern larger Europe. Many papers have limited their concerns on Western Europe, e.g. [8, 9, 19].

This paper aims to evaluate and compare the efficiency level of railway companies from larger Europe, considering railway companies from WE, as well as from CEE, and the analysis will indicate differences in performance between railway companies that reached higher level of structural reforms (e.g. Western Europe), and companies which are step behind in that sense (e.g. former Soviet Republic).

In order to evaluate and compare efficiency of railway companies, two-stage analysis will be employed. In the first stage efficiency scores will be obtained using DEA, where efficiency scores will be obtained separately for passenger and freight transportation, as well as for overall transportation. Different approaches in inputs-outputs selection will be considered by implementing respective models.

Since the selection of variables represents critical point in the analysis, this paper aims to compare results from different approaches and analyze the impact of variables selection process on possible conclusions and decisions made based on efficiency analysis. These differences will be inspected using different correlation tests. In order to determine differences in performance between railway companies from WE and CEE countries, next hypothesis is set:

Hypothesis 1: There is a difference in efficiency scores of railway companies from WE and CEE countries.

The hypothesis 1 will be tested by applying nonparametrical Mann-Whitney test. Additionally, Tobit regression analysis will be employed in order to evaluate the influence of different environmental factors on railways' efficiency level.

Next section describes the methodology of DEA and Tobit. Results of empirical analysis are shown in the Section 3. Section 4 contains concluding remarks of this study.

\section{METHODOLOGY}

\subsection{Data Envelopment Analysis}

The basic idea and the definition of the concept of DEA was introduced by Farrell [10]. Based on his wo$\mathrm{rk}$, the linear programming model was developed by Charnes, Cooper and Rhodes [5]. Their work is considered as the beginning of DEA.

Considering the scale efficiency, two different models of the DEA method can be used in evaluation of the efficiency of decision making units (DMUs), the CCR model with constant return to scale [5] and the BCC model with variable return to scale [3]. This paper employs CCR DEA model, which gives gross efficiency values of the DMUs which are observable from the input/output data, and it is comparable with other non-parametric methods, while BCC decomposes overall efficiency into technical efficiency and scale efficiency [19].

Regarding orientation of the distance function, in [6] it is stated that the choice of orientation of the distance function is not as important in case of railway companies as for other industries.

This paper employs input orientated models, assuming that the railway companies have a higher influence on the inputs than on the outputs, since the output volumes are influenced by different macroeconomic and exogenous factors [19].

Input oriented CCR DEA model employed in this paper has the following form $[4,7,15]$ :

$$
(\max ) h_{k}=\sum_{r=1}^{s} u_{r} y_{r k}
$$

with constraints:

$$
\begin{aligned}
& \sum_{i=1}^{m} v_{i} x_{i k}=1 \\
& \sum_{r=1}^{s} u_{r} y_{r j}-\sum_{i=1}^{m} v_{i} x_{i j} \leq 0, \quad j=1, \ldots, n \\
& u_{r}>0, \quad r=1, \ldots, s \\
& v_{i}>0, \quad i=1, \ldots, m
\end{aligned}
$$

where $h_{k}$ denotes efficiency of $k$-th DMU, $k=1, \ldots, n ; y_{r}$ is the $r$-th output, $r=1, \ldots, s ; x_{i}$ is the $i$-th input, $i=1, \ldots, m$; and $u_{r}$ and $v_{i}$ are weighting coefficients which are to be determined.

\subsection{Tobit Analysis}

When the efficiency scores calculated by DEA are used as dependent variables in regression, we find a good example of censoring, which means that the values of the dependent variable are limited to a range of values. More precisely, censoring occurs when the dependent variable is observed as a subsample, while information about independent variables for the entire sample is available. In our case, all companies on the efficiency frontier are considered fully efficient, and receive a value of 1 as their efficiency score, even though their efficiency levels are not truly equal.

This is why the Tobit model (also known as the censored regression model) will be used to determine the efficiency drivers of railway companies.

„Upper censoring“ Tobit model, as in the efficiency scores with upper limit 1 , may be expressed as follows, with $y$ denoting values of the observed variable (efficiency) $[11 ; 15]$ :

$$
y_{i}^{*}=x_{i}{ }^{\prime} \beta+u_{i}
$$




$$
y=\left\{\begin{array}{ccc}
y^{*} & \text { ise } & y^{*}<1 \\
1 & \text { ise } & y^{*} \geq 1
\end{array}\right.
$$

where $x_{i}$ is observed independent variable for all situations, $\beta$ denotes estimation factors and $u_{i} \square\left[0, \sigma^{2}\right]$ denotes the error (destructive) term.

A Tobit model structured in this manner can be evaluated using the maximum likelihood method. The direct ordinary least squares (OLS) regression on calculated efficiency scores from DEA $\left(y_{i}\right)$ and the variable means $\left(x_{i}\right)$ contributes to inconsistent values for $\beta$.

\section{EMPIRICAL ANALYSIS}

The aim of this paper is the efficiency analysis of railway companies from larger Europe during the time period of ten years, between 2004 and 2013. Data set includes 34 European railway companies (Table 1). Data were obtained from the official statistics of International Union of Railways ${ }^{1}$ The efficiency evaluation is conducted separately for each year of the time period observed, so possible random errors or yearly upturns can be detected.

As some companies have been operating as integrated (infrastructure maintenance and transportation operations performed by same company) values of inputs and outputs were taken as they are when compiling the data, while for the companies which conducted vertical separation the respective values have been obtained from different companies considering the relations among them [15].

Since there have been difficulties in obtaining data for some companies in certain years of the time period observed they were omitted in the analysis for respective years.

Companies from Denmark, Netherlands, Norway and Sweden provide only passenger transportation service, thus they are included only in models that concern passenger transportation service. Hungarian company MÁV Cargo, which has been providing freight transportation service as part of the national company MÁV, was sold in 2008 to Austrian company Rail Cargo Austria, thus it was omitted in the analysis in the period 2009-2013.

In order to obtain consistent results, all the relevant input/output factors regarding the problem observed have to be determined [16]. Regarding railways industry, there are different approaches in inputs/outputs selection $[12,13,15,20,21]$.

${ }^{1}$ UIC (International Union of Railways), Railisa Database, Available on: http://www.uic.org/statistics
Table 1. Railway companies included in the analysis

\begin{tabular}{|c|c|}
\hline Country & Company (DMU) \\
\hline Austria & OBB \\
\hline Belarus & $\mathrm{BC}$ \\
\hline Belgium & SNCB/NMBS \\
\hline Bosnia \& Herzegovina & ZFBH/ZRS \\
\hline Bulgaria & $\mathrm{BDZ}$ \\
\hline Croatia & $\mathrm{HZ}$ \\
\hline Czech Republic & $\mathrm{CD}$ \\
\hline Denmark & DSB \\
\hline Estonia & EVR \\
\hline Finland & VR \\
\hline France & SNCF \\
\hline Germany & DBAG \\
\hline Greece & OSE \\
\hline Hungary & MAV \\
\hline Ireland & $\mathrm{CIE}$ \\
\hline Italy & $\mathrm{FS}$ \\
\hline Latvia & LDZ \\
\hline Lithuania & LG \\
\hline Luxembourg & CFL \\
\hline Macedonia & $\mathrm{MZ}$ \\
\hline Moldova & CFM \\
\hline Netherlands & NS \\
\hline Norway & NSB \\
\hline Poland & PKP \\
\hline Portugal & $\mathrm{CP}$ \\
\hline Romania & CFR \\
\hline Serbia & $\mathrm{ZS}$ \\
\hline Slovak Republic & ZSSK/ZSR \\
\hline Slovenia & SZ \\
\hline Spain & RENFE \\
\hline Sweden & SJAB \\
\hline Switzerland & SBB/CFF/FFS \\
\hline Turkey & TCDD \\
\hline Ukraine & $\mathrm{UZ}$ \\
\hline
\end{tabular}

This paper employs five input variables:

- $x_{1}$ - Total length of railway network lines (kilometers);

- $\quad x_{2}-$ Total number of employees (thousands);

- $x_{3}$ - Total number of locomotives;

- $x_{4}$ - Total number of passenger cars;

- $x_{5}$ - Total number of freight wagons.

- Five output variables observed in this paper are:

- $y_{1}$ - Passengers carried (millions);

- $y_{2}$-Passenger-kilometers achieved (millions);

- $y_{3}$-Freight Tons carried (millions);

- $y_{4}$-Freight Ton-kilometers achieved (millions); 
- $y_{5}-$ Train kilometers achieved (millions).

Some authors [19, 21], use passenger trainkilometers and freight train-kilometers separately, as two different outputs. Since the official statistics ${ }^{1}$ do not provide data for passenger and freight trainkilometers separately for all companies observed which provide both, passenger and freight transportation service, this paper employs single-output $\left(y_{5}\right)$ as the total number of (passenger and freight) trainkilometers achieved.

Six different DEA models are developed (Table 2). Two different single-output DEA models for passenger service and two different single-output DEA models for freight service efficiency evaluation are adopted from [13]. In order to evaluate overall efficiency of railway companies which provide both, passenger and freight transportation service, two additional (twooutputs and single-output, respectively) models are used.

Table 2. Specification of DEA models

\begin{tabular}{|l|l|l|l|l|l|l|l|}
\hline I/O & \multirow{2}{*}{ Var. } & \multicolumn{6}{|c|}{ Model } \\
\cline { 3 - 8 } & & M1 & M2 & M3 & M4 & M5 & M6 \\
\hline I & $x_{1}$ & $\bullet$ & $\bullet$ & $\bullet$ & $\bullet$ & $\bullet$ & $\bullet$ \\
\hline & $x_{2}$ & $\bullet$ & $\bullet$ & $\bullet$ & $\bullet$ & $\bullet$ & $\bullet$ \\
\hline & $x_{3}$ & $\bullet$ & $\bullet$ & $\bullet$ & $\bullet$ & $\bullet$ & $\bullet$ \\
\hline & $x_{4}$ & $\bullet$ & $\bullet$ & & & $\bullet$ & $\bullet$ \\
\hline & $x_{5}$ & & & $\bullet$ & $\bullet$ & $\bullet$ & $\bullet$ \\
\hline O & $y_{1}$ & $\bullet$ & & & & & \\
\hline & $y_{2}$ & & $\bullet$ & & & $\bullet$ & \\
\hline & $y_{3}$ & & & $\bullet$ & & & \\
\hline & $y_{4}$ & & & & $\bullet$ & $\bullet$ & \\
\hline & $y_{5}$ & & & & & & $\bullet$ \\
\hline & FCC & 0.97 & 0.98 & 0.96 & 0.96 & 0.98 & 0.97 \\
\hline
\end{tabular}

Considering selection of variables in DEA, one of the main aspects is a high between-group correlation, i.e. all outputs should be directly generated by inputs [14]. For this purpose, canonical correlation analysis is applied, aiming to measure and quantify the dependence between the set of inputs and set of outputs. According to the first canonical correlation (FCC) coefficients (Table 2), all DEA models show relatively high correlation between set of inputs and set of outputs considered.

\subsection{Results of Data Envelopment Analysis}

Considering large scale of results data, efficiency scores are plotted in Figure 1. Solving DEA models, as well as all other computations in this paper were conducted using Stata software ${ }^{2}$.

${ }^{2}$ Stata software, Available on: http://www.stata.com/

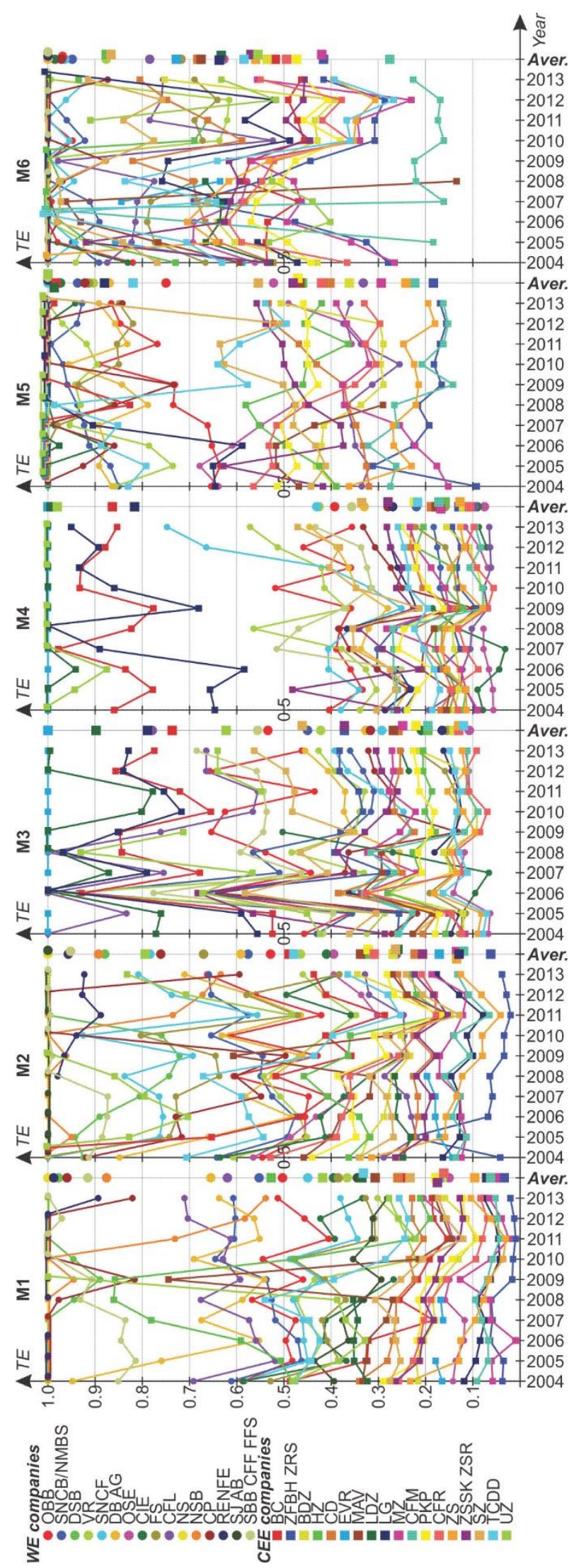

Figure 1-DEA results

Regarding efficiency of passenger transportation service (M1 and M2), companies DSB, NS, NSB, CP, 
RENFE and SBB represent benchmarks for other companies in both models. NS is the only company efficient during the whole period observed. NSB experienced performance decline in the last three years of the period observed, as well as BC, FS and CFR during the whole period, while the SBB company experienced improvement in efficiency level in the second half of the period observed. According to M2, SJAB was efficient during the whole period, while according to M1 it showed poor efficiency level. It could be consequence of the nature of passengers' journeys in Sweden (dominance of long-distance journeys). Other well performing companies (above 50\% efficiency level in average) in both models are: OBB, SNCB and DBAG; in M1: HZ and CFL; and in M2: SNCF, FS and UZ. Except companies NSB, BC, FS, $\mathrm{CFR}$ and $\mathrm{SBB}$, there are no clear trends in performance of railway companies during the period observed, in sense of constant increasing or decreasing of efficiency level.

According to results of M3 and M4 (freight transportation service) the best performance showed company EVR, which is the only company efficient during the whole period. Other companies with high efficiency level, and which represent benchmarks for other companies are: BC, LDZ, LG and UZ. CFL showed largest difference in efficiency level between these two models - while it showed high efficiency level in M3, it demonstrated very low performances in M4. It could be explained with dominance of shorter distances in freight transport. It can be seen that there is very small number of companies that show good performance in both, passenger and freight transportation services. It can be explained with fact that railway companies are oriented either on passenger or freight transportation service. Other well performing companies are OBB and SBB, both in M3. Lowest efficiency level have companies OSE and CIE, both below $10 \%$ in average according to M4. Except DBAG, which showed improvement in efficiency level, there are no clear trends in performance of railway companies during the period observed, thus the results are rather mixed.

According to results of M5 and M6 (overall transportation efficiency), these two models differ the most in efficiency scores obtained.

Efficient companies during the whole period are RENFE and OBB (both models); SNCF, EVR and UZ (M5); and DBAG (M6). Other companies with high efficiency level (above 50\% in average) according to both models are: OBB, SNCB, VR, CIE, FS, CP, LDZ, LG, SZ and TCDD. Companies CFL, BDZ, HZ, CD, MAV, ZS and ZSSK also have efficiency level above $50 \%$ in average according to results of M6. In contrast to the results of previous four DEA models, there are no efficiency scores below $10 \%$.

\subsection{Comparison of results}

In order to investigate influence of outputs selection and analyze difference between efficiency scores obtained from different DEA models, Pearson's and Spearman's rank correlation tests are conducted. Results are given in Table 3 . Relatively high values of coefficients may indicate very similar values of efficiency scores obtained from different DEA models.

Table 3. Comparison of DEA scores using Pearson and Spearman rank correlation

\begin{tabular}{|c|c|c|c|c|c|c|c|}
\hline Method & Model & M1 & M2 & M3 & M4 & M5 & M6 \\
\hline Pearson correlation & \multirow[t]{2}{*}{ M1 } & 1 & & & & & \\
\hline Spearman rank correlation & & 1 & & & & & \\
\hline Pearson correlation & \multirow[t]{2}{*}{ M2 } & $0.8047 * *$ & 1 & & & & \\
\hline Spearman rank correlation & & $0.8248 * *$ & 1 & & & & \\
\hline Pearson correlation & \multirow[t]{2}{*}{ M3 } & 0.0831 & -0.0211 & 1 & & & \\
\hline Spearman rank correlation & & $0.1706^{* *}$ & 0.0296 & 1 & & & \\
\hline Pearson correlation & \multirow[t]{2}{*}{ M4 } & -0.0031 & $0.1532 *$ & $0.7550 * *$ & 1 & & \\
\hline Spearman rank correlation & & $0.2043 * *$ & $0.3032 * *$ & $0.6680 * *$ & 1 & & \\
\hline Pearson correlation & \multirow[t]{2}{*}{ M5 } & $0.5495^{* *}$ & $0.7204 * *$ & $0.3450 * *$ & $0.5824 * *$ & 1 & \\
\hline Spearman rank correlation & & $0.5479 * *$ & $0.7166^{* *}$ & $0.3585 * *$ & $0.6563 * *$ & 1 & \\
\hline Pearson correlation & \multirow[t]{2}{*}{ M6 } & $0.7192 * *$ & $0.5835^{* *}$ & $0.1569 *$ & 0.0367 & $0.5837 * *$ & 1 \\
\hline Spearman rank correlation & & $0.7771 * *$ & $0.6250 * *$ & $0.2109 * *$ & $0.2465^{* *}$ & $0.5498 * *$ & 1 \\
\hline
\end{tabular}

* Denotes statistical significance at level $\alpha=5 \%$, and ** at level $\alpha=1 \%$, using two-tailed test

Relatively high and statistically significant correlation between efficiency scores is identified between models within each of three groups (M1-M2, M3-M4,
M5-M6), as well as between pairs M1-M5, M2-M5, M1-M6 and M2-M6, indicating that two sets of DEA models which analyze passenger and overall 
transportation efficiency produce very similar results. In contrast, there are large differences in efficiency scores obtained from the two sets of DEA models which analyze passenger and freight transportation efficiency. The influence of outputs selection can also be seen in correlation coefficient values between DEA models which analyze freight and overall transportation efficiency. While there are medium and relatively strong correlation between M3 and M5, and M4 and M5, values of correlation coefficients between M3 and M6, as well as between M4 and M6, indicate low correlation.

As stated within the Introduction, differences in efficiency scores of railway companies from WE and CEE countries are determined by testing hypothesis 1 separately for each DEA model by using non-parametrical Mann-Whitney test, which results indicate whether the efficiency scores differ between subgroups in observed sample. Considering that the tested technical efficiency scores are not normally distributed, non- parametrical test is used instead of variance analysis [2]. The results are presented in Table 4.

Considering M1 and M2, $p$ value at Mann-Whitney test indicates in favor of rejecting null hypothesis and accepting hypothesis 1 .

Observing rank sum, it can be concluded that railway companies from WE countries have higher rank than those from CEE countries. Regarding M3, results indicate that there are no reasons for rejecting null hypothesis, with significance level $\alpha=0.05$. Although companies from CEE countries showed higher level of efficiency in M4, there are no statistically significant differences in efficiency scores between the two observed groups, so hypothesis 1 is rejected.

Considering last two DEA models, there are statistically significant differences in efficiency scores and railway companies from WE countries have higher efficiency scores than companies from CEE countries. Hypothesis 1 is accepted for both models.

Table 4. Results of Mann-Whitney test

\begin{tabular}{|l|l|l|l|l|l|l|l|}
\hline \multirow{2}{*}{ Region } & \multirow{2}{*}{} & \multicolumn{7}{|c|}{ Model } \\
\cline { 3 - 8 } & & M1 & M2 & M3 & M4 & M5 & M6 \\
\hline CEE & Obs. & 168 & 169 & 173 & 174 & 164 & 158 \\
\hline & Rank sum & 16476.5 & 16844 & 24766.5 & 25618 & 18066.5 & 14185 \\
\hline & Expected & 27384 & 27631.5 & 24998.5 & 25230 & 22960 & 21251 \\
\hline WE & Obs. & 157 & 157 & 115 & 115 & 115 & 110 \\
\hline & Rank sum & 36498.5 & 36457 & 16849.5 & 16287 & 20993.5 & 21861 \\
\hline & Expected & 25591 & 25669.5 & 16617.5 & 16675 & 16100 & 14795 \\
\hline$Z$ & -12.899 & -12.701 & -0.335 & 0.558 & -7.452 & -11.410 \\
\hline$p$-value $(\alpha=0.05)$ & 0.0000 & 0.0000 & 0.7375 & 0.5767 & 0.0000 & 0.0000 \\
\hline
\end{tabular}

\subsection{Tobit Analysis}

Using efficiency scores obtained from DEA models in the first stage as dependent variables, six Tobit models are developed (TM1-TM6), aiming to evaluate the impact of certain exogenous factors, representing macroeconomic and demographic characteristics of a country, as well railway infrastructure development characteristics, on the efficiency of railway companies. Independent variables considered in this paper are:

- $z_{1}-$ GDP per capita (GDP divided by midyear population, expressed in US dollars);

- $z_{2}$ - Population density (midyear population divided by land area in square kilometers);

- $z_{3}$ - Railway network density (total length of railway lines in kilometers divided by land area in square kilometers);

- $\quad z_{4}$ - Percentage of double or multi track lines;

- $z_{5}$-Percentage of electrified lines.
Data for $z_{1}$ and $z_{2}$ are obtained from World Bank database ${ }^{3}$, and for $z_{3}, z_{4}$ and $z_{5}$ from the official statistics of International Union of Railways ${ }^{1}$.

Results of Tobit analysis are given in Table 5. Considering variable $z_{1}$, results of all Tobit models, except TM4, indicate that it has statistically significant and positive impact on railways' efficiency, thus, it could be argued that more developed countries have higher efficiency level in railway transportation services.

Regarding variable $z_{2}$, it is statistically significant in the first four models, with positive influence on efficiency of passenger transportation service, and negative influence on efficiency of freight transportation service. Although there are opposite values of coefficients regarding overall transportation (TM5 and TM6) it has no statistical significance.

\footnotetext{
${ }^{3}$ World Bank, World DataBank, Available on: http://databank.worldbank.org/data/home.aspx
} 
Variable $z_{3}$ has significant and negative influence on passenger transportation service efficiency, while results are mixed regarding other four models. Negative impact could be explained as a consequence of excessive engagement of input variable (length of lines), contributing to lower efficiency level. Variable $z_{4}$ has positive influence on efficiency of railway companies in all models. This matched our expectations, since the existence of double and multitrack lines provides higher traffic volume.

Variable $z_{5}$ has positive influence on efficiency in passenger transportation and negative influence on efficiency in freight and overall transportation. It could be argued that consumption of conventional fuel in traction is preferred in freight transportation, while electrification of lines contributes to higher efficiency level in passenger transport operations.

Opposite signs of coefficients of some indicators for passenger and freight transportation may be a consequence of mutual resource usage and different orientation of railway companies [15]. For example, countries with high population density are oriented to transport large numbers of passengers, putting freight transportation in the background.

Table 5. Results of Tobit analysis

\begin{tabular}{|c|c|c|c|c|c|c|c|c|c|c|c|c|}
\hline \multirow[t]{2}{*}{ Var. } & \multicolumn{2}{|l|}{ TM1 } & \multicolumn{2}{|l|}{ TM2 } & \multicolumn{2}{|l|}{ TM3 } & \multicolumn{2}{|l|}{ TM4 } & \multicolumn{2}{|l|}{ TM5 } & \multicolumn{2}{|l|}{ TM6 } \\
\hline & Coef. & $t$ & Coef. & $t$ & Coef. & $t$ & Coef. & $t$ & Coef. & $t$ & Coef. & $t$ \\
\hline Cnst.. & $0.152 * *$ & 4.5 & $0.287 * *$ & 8.6 & $0.402 * *$ & 11.9 & $0.540 * *$ & 15.6 & $0.731 * *$ & 17.2 & $0.560 * *$ & 15.3 \\
\hline$z 1$ & $0.001 * *$ & 10.1 & $0.001 * *$ & 7.0 & $0.001 * *$ & 3.4 & -0.001 & -1.7 & $0.001 * *$ & 3.8 & $0.001 * *$ & 7.6 \\
\hline$z 2$ & $0.002 * *$ & 6.9 & $0.002 * *$ & 6.0 & $-0.002 * *$ & -5.4 & $-0.002 * *$ & -6.1 & \begin{tabular}{|l|}
-0.001 \\
\end{tabular} & -0.4 & 0.001 & 0.5 \\
\hline$z 3$ & $-3.752 * *$ & -5.4 & $-6.469 * *$ & -9.3 & $1.773 *$ & 2.2 & -0.059 & -0.1 & $-6.227 * *$ & -6.8 & \begin{tabular}{|l|}
-1.193 \\
\end{tabular} & -1.5 \\
\hline$z 4$ & 0.001 & 0.9 & $0.004 * *$ & 4.0 & $0.005^{* *}$ & 3.7 & $0.010 * *$ & 7.8 & $0.016^{* *}$ & 9.6 & $0.004 * *$ & 3.0 \\
\hline$z 5$ & 0.001 & 0.9 & $0.002 * *$ & 3.3 & $-0.002 *$ & -2.1 & $-0.004 * *$ & -4.3 & $-0.004 * *$ & -4.5 & -0.001 & -1.2 \\
\hline Cens. & \multicolumn{2}{|l|}{$42(325)$} & \multicolumn{2}{|l|}{$43(326)$} & \multicolumn{2}{|l|}{$17(288)$} & \multicolumn{2}{|l|}{27 (289) } & \multicolumn{2}{|l|}{$76(279)$} & \multicolumn{2}{|l|}{$67(268)$} \\
\hline
\end{tabular}

* Denotes statistical significance at level $\alpha=5 \%$, and ** at level $\alpha=1 \%$, using two-tailed test

\section{CONCLUSIONS}

This paper employed two-stage analysis aiming compare performances of 34 railway companies from larger Europe, during the ten year period between 2004 and 2013. First DEA method was used in obtaining efficiency scores, and then, different statistical tests and Tobit analysis were used in order to analyze impact of inputs and outputs selection, as well as exogenous factors, on European railways efficiency.

Proposed methodology can provide companies insight in their business performances and possibility to monitor and improve their efficiency level. Future research will include application of double-bootstrap methodology and conditional efficiency measures.

\section{ACKNOWLEDGEMENT}

This work was partially supported by Ministry of Education, Science and Technological Development, Republic of Serbia, through the project TR36022.

\section{REFERENCES}

[1] Affuso L, Alvaro A, Pollitt M. Measuring the Efficiency of Britian's Privatized Train Operating Companies, Regulation Initiative Discussion Paper Series, No. 48, London Business School, 2002.

[2] Andrejić M, Bojović N, Kilibarda M. Benchmarking distribution centres using Principal component analysis and Data Envelopment Analysis: A case study of Serbia, Expert Systems with Applications, Vol. 40, pp. 3926-3933, 2013.

[3] Banker RD, Charnes A, Cooper WW. Some Models for Estimating Technical and Scale Inefficiencies in Data Envelopment Analysis, Management Science, Vol. 30, No. 9, pp. 1078-1092, 1984.

[4] Bojović N, Milenković M, Kapetanović M, Knežević N. Innovations Impact on Efficiency of European Railway Companies, Management: Journal for Theory and Practice Management, Vol. 21, No. 79, pp. 13-25, 2016.

[5] Charnes A, Cooper WW, Rhodes E. Measuring Efficiency of Decision Making Units, European Journal of Operational Research, Vol. 2, pp. 429444, 1978.

[6] Coelli T, Perelman S. Technical efficiency of European railways: a distance function approach, Applied Economics, Vol. 32, No. 15, pp. 1967-1976, 2000.

[7] Daraio C, Simar L. Introducing environmental variables in nonparametric frontier models: a probabilistic approach, Journal of productivity analysis, Vol. 24, No. 1, pp. 93-121, 2005.

[8] De Jorge J, Suarez C. Has the efficiency of European railway companies been improved?, European Business Review, Vol. 15, pp. 213-220, 2003. 
[9] De Jorge-Moreno J, Garcia-Cebrian LI. Measuring of production efficiency in the European railways, European Business Review, Vol. 99, pp. 332-344, 1999.

[10]Farrell MJ. The Measurement of Productive Efficiency, Journal of the Royal Statistical Society. Series A (General), Vol. 120, No. 3, pp. 253-290, 1957.

[11]Greene WH. Econometric analysis, 3rd edn. Prentice Hall, New Jersey, 1997.

[12]Hilmola O-P. European Railway Freight Transportation and Adaptation to Demand Decline Efficiency and Partial Productivity Analysis from Period of 1980-2003, International Journal of Productivity and Performance Management, Vol. 56, No. 3, pp. 205-225, 2007.

[13]Hilmola O-P. Railway efficiency analysis from larger Europe during the period 1994-2003, Int. J. Operational Research, Vol. 3, No. 3, pp. 255-280, 2008.

[14]Král' P, Roháčová V. Measuring The Efficiency of Public Road Transport Companies in the Slovak Republic using DEA and SFA, Statistika: Statistics and Economy Journal, Vol. 93, No. 2, pp. 76-85, 2013.

[15]Kutlar A, Kabasakal A, Sarikaya M. Determination of the efficiency of the world railway companies by method of DEA and comparison of their efficiency by Tobit analysis, Quality\&Quantity, Vol. 47, pp. 3575-3602, 2013.
[16]Mawson P, Carlaw KI, McLellan N. Productivity measurement: Alternative approaches and estimates, Treasury Working Paper 03/12, New Zealand, 2003.

[17]Merkert R, Smith A, Nash C. The institutional, environmental and transactional factors on train operating company performance - A Tobit regression approach based on DEA efficiency scores, European Transport Conference, Noordwijkerhout, Netherlands, 2009.

[18]Nashand ASJ, Nash CA. Benchmarking of train operating firms: a transaction cost efficiency analysis, Transp. Plan. Technol., Vol. 33, No. 1, pp. 35-53, 2010.

[19]Oum TH, Yu C. Economic Efficiency of Railways and Implications for Public Policy, Journal of Transport Economics and Policy, Vol. 18, No. 2, pp. 121-138, 1994.

[20]Yu M. Assessing the technical efficiency, service effectiveness, and technical effectiveness of the world's railways through NDEA analysis, Transportation Research Part A, Vol. 42, pp. 12831294, 2008.

[21] Yu MM, Lin TJE. Efficiency and effectiveness in railway performance using a multi-activity network DEA model, Omega - International Journal of Management Science, Vol. 36, No. 6, pp. 1005-1017, 2008.

\section{REZIME \\ OCENA EFIKASNOSTI EVROPSKIH ŽELEZNIČKIH KOMPANIJA: PRIMENA DVOSTEPENE ANALIZE}

Cilj ovog rada je ocena efikasnosti železničkih komanija iz većeg dela Evrope, tokom najskorijeg vremenskog perioda, analizirajući različite ulazno-izlazne konfiguracije modela. Primenjena je dvostepena analiza, gde su u prvoj fazi ocene efikasnosti dobijene pomoću DEA metode, dok su u drugoj fazi sprovedeni različiti statistički testovi, kao i Tobit analiza, sa ciljem ocene uticaja različitih egzogenih faktora na nivo efikasnosti. Rezultati su pokazali da su železničke kompanije orijentisane ili na putnički ili teretni prevoz, uz samo nekoliko komanija sa visokim performansama u oba vida. Kompanije iz Zapadne Evrope pokazale su bolje performanse od kompanija iz Centralne i Istočne Evrope kada je reč o putničkom i ukupnom saobraćaju, dok su rezultati suprotni kada se posmatra samo teretni prevoz. Osim nekoliko kompanija, ne postoje jasni trendovi tokom posmatranog perioda, u vidu konstantnog poboljšanja ili smanjenja nivoa efikasnosti. Identifikovan je visok uticaj izbora ulaznoizlaznih faktora.

Ključne reči: železnica, efikasnost, analiza obavijanja podataka, tobit analiza 